\title{
Canadian Classics New and Old
}

Although the other chapters in this volume are focused on the best new picture books, this chapter spotlights some Canadian titles of exceptional quality, published before 2017, that we think are groundbreaking as change-agents in the field of children's literature. They have either already remained highly relevant over time, or else we predict their lasting qualities. We call these titles "Canadian Classics New and Old."

We think these books will continue to capture the hearts and minds of young readers. Some of them will also offer nostalgic connections for adults who read them in years gone by. Because quality children's literature takes us back into childhood rather than simply talking about childhood, adult readers have an opportunity to time travel into their younger years by reading these titles, which can appeal to all ages.

In addition to offering a summary of the content of each of the books we have selected for this section, we have also included special indications of merit or aspects of titles that we think demonstrated new ways of seeing and representing the world at the time of publication. This originality can be thought of as Radical Change, a term coined by Dr. Eliza Dresang as she researched the evolution of children's literature. In her view, the content and design of children's books is shifting over time, partly as a result of influences from the digital world. The three areas of change she lists are: new forms and formats; changing perspectives; and changing boundaries. We have grouped the titles in this chapter under these topic headings as a way to think about their contributions to radical in the field of children's books.

While we have given suggestions about audience age regarding the books summarised in earlier chapters, we open the titles in this chapter to wider considerations because of their ability to stand the test of time, and/or the innovations they present to the picture book field. For this reason, we have not included an age range for the titles summarised in this section.

The books here definitely break the mold when it comes to forms and formats. There are titles that combine graphic novel conventions such as speech bubbles, font, and colour use with more conventional picture book traditions.

(C) BEVERLEY BRENNA, RICHARD DIONNE AND THERESA TAVARES, 2021 
Some of the non-fiction titles use sidebars and other design choices that reflect online reading. Books with seemingly unfinished endings and non-sequential storylines also appear in this category as well as stories that have shifted from one form to another.

Where not otherwise indicated, the name of the author(s) appears first under each title, and the illustrator last. We have also included the original year of publication after the title.

\section{Buttercup's Lovely Day (2008) \\ Carolyn Beck \\ and Andrea Beck}

Rhyming text carries us through a day in the life of a joyful Holstein whose motto is "It's so so fine/ to be bovine." Carolyn Beck plays with humour in tremendously original vocabulary sequences that include "the fluzz of the flies" and "stinky slinky funky skunk." Her sister Andrea Beck has created dazzling acrylics that overflow with greens and blues.

Mary of Mile 18 (1971)

Ann Blades

A girl who finds a wolf pup is forbidden to keep it as a farm pet until it proves its worth in alerting the family to coyotes. Ann Blades was a 19-yearold teacher in remote British Columbia (Mile 18, now called Buick) when she wrote and illustrated this book, inspired by the lack of titles reflecting her students' lives. Originally published in 1971, it is one of the first Canadian titles in full colour, and was awarded Book of the Year by the Canadian Library Association.
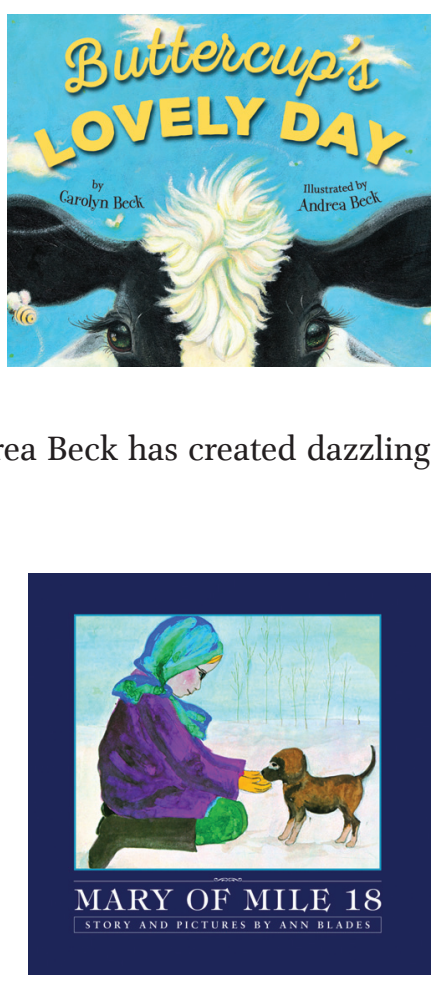

sari of mite 18

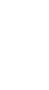


The Hockey Sweater (1984, from a short story first published in 1979) Roch Carrier,

Sheila Fischman (translator) and Sheldon Cohen

This autobiographical adult short story, originally in French, was adapted into an animated

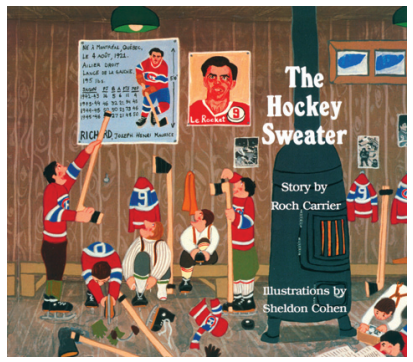
short film as well as this brightly illustrated picture book. It is an iconic piece of Canadian literature, and some audiences interpret it as an allegory for tensions between francophone and anglophone communities. A line from this story appears on Canadian five-dollar-bills as part of the Canadian Journey banknote series, making Carrier the first author to be quoted in this way.

\section{Water's Children: Creating the}

Resource that Unites Us All

(2006, French; 2017, English)

Angèle Delaunois,

Erin Woods (translator)

and Gérard Frischeteau

The importance of water unfolds from twelve different perspectives as young people around the world describe in lyrical text what

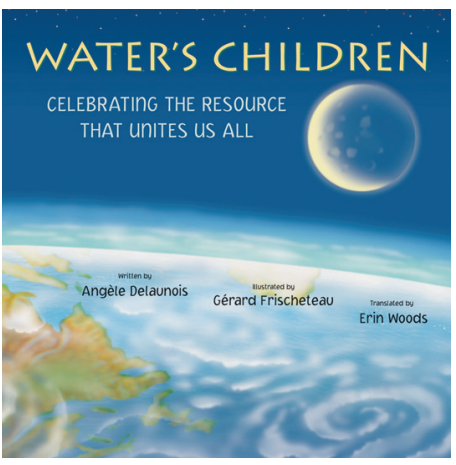
water means to them. The final page offers translations of the various languages used in order to metaphorically describe how water is important. This title was first published in Quebec, in French, and received many positive reviews for both text and illustrations.

\section{Lii Yiiboo Nayaapiwak lii Swer: L'alfabet di Michif/Owls See Clearly at Night: A Michif Alphabet (2010) \\ Julie Flett}

This is a bilingual alphabet book that uses Michif as the book's primary language and English secondarily. While alphabet books have traditionally been seen as only resources for younger children, this beautiful book promotes Métis culture and supports the growth of a language at risk of being lost. 
Baseball Bats for Christmas (1990)

Michael Arvaarluk Kusugak

and Vladyana Krykorka

This story from Inuit author Michael Kusugak flows from the oral storytelling tradition, and during its 1990 debut, it was praised for its fresh, original voice on the landscape of children's picture books. Six-year-old Arvaarluk is an asthmatic Inuit boy who loves baseball; his friend takes an axe to one of the mysterious trees a bush pilot leaves at the local store, and all the

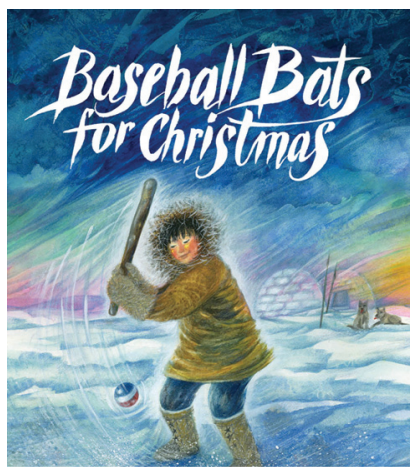

Michael Arvaarluk Kusugak ₹ Vladyana Krykorka young people in Repulse Bay learn the game.

As Long as the Rivers Flow (2002)

Larry Loyie,

Constance Brissenden

and Heather D. Holmlund

Larry Loyie (Oskiniko) was an award-winning Canadian author and playwright of Cree ancestry who was known for works about his childhood residential school experiences. This picture book tells about his last summer prior to entering the St. Bernard Indian Residential School in Grouard, Alberta, which he attended between the ages of 9 and 14. The book,

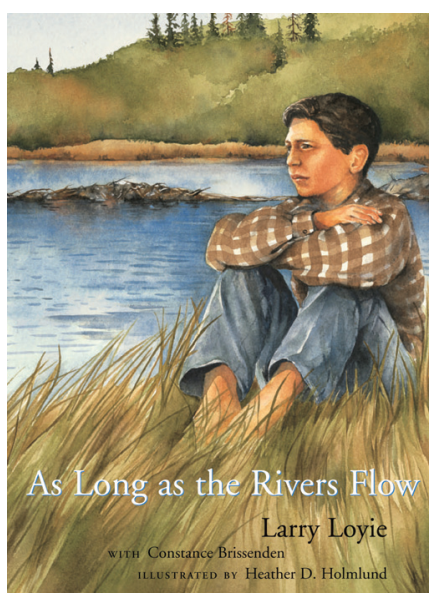
uniquely written in four chapters, contain autobiographical episodes. Its title, spoken by Larry's grandfather as a reminder to his grandchildren, foreshadows words spoken years later by Chief Dan George. 
Waiting for the Whales (1991)

Sheryl McFarlane

and Ron Lightburn

This multi-award winning title (for both author and illustrator) was described as "timeless" when it was originally published in 1991. In prose that suggests non-fiction, it follows the circle of life for both a human family and a pod of whales, with nameless characters that foster empathy. Aspects of the story are left unexplained, and readers fill in the blanks through text-based

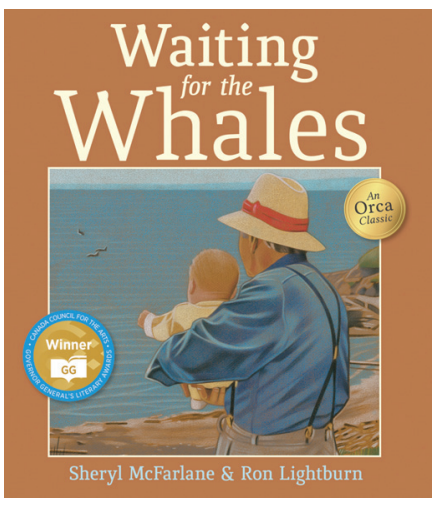
inferences as well as personal connections.

Josepha: A Prairie Boy's Story (1994)

Jim McGugan

and Murray Kimber

This story, set on the prairies in 1900, follows a friendship between two boys, one of whom is an older immigrant remaining in the primary row at school because he hasn't learned English. Unusual choices in perspective make Murray Kimber's illustrations really stand out, and the story itself has an ending that is unique in a gentle deviation from happily-ever-after.

\section{Mortimer (1983) \\ Robert Munsch \\ and Michael Martchenko}

Classic Munsch, this book resounds with exuberance, as its repeated refrains entice young children to chime in as noisily as possible, encouraged by bolded text. As with many of Robert Munsch's titles, it fastens on a particularly common child-

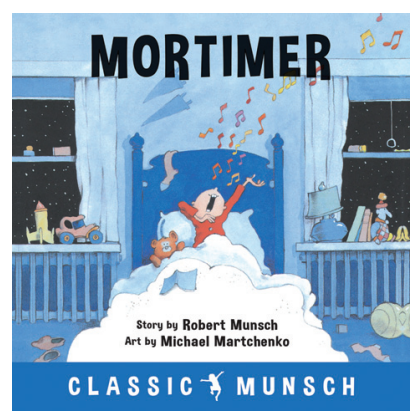
hood experience - in this instance, aversion to bedtime - and plays it up into a performance of over-the-top characters and delightful child-centred humour. All Munsch works, loved by decades of children, began as stories that he told to youngsters, and his written work resounds with polish from those repeated tellings. 
My Family Tree and Me (2015)

Dušan Petričić

This is one child's exploration of his family tree, uniquely borrowing from a "photo album" style that works splendidly with this subject matter. The book's front-to-middle is dedicated to the boy's father's side of the family, while the back-to-middle is devoted to his mother's family, and thus various directions of page-turning are encouraged.

\section{The Party (1997)}

\section{Barbara Reid}

This popular title encourages multiple readings to discover all the small details of a family birthday party hidden in the three-dimensional illustrations captivatingly created with plasticine, which is shaped and pressed onto an illustration board. Acrylic paint and other materials are also used for special effects. What is important in this subject matter is the full range of experiences shared by two

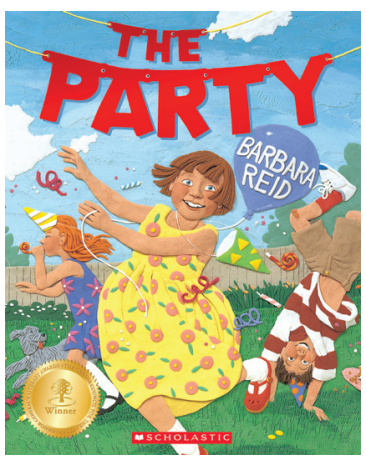
sisters in a yard full of relatives.

\section{Away (2017) \\ Emil Sher \\ and Qin Leng}

Summer camp is approaching and Skip doesn't want to go. A series of interactions between mother and daughter shifts her unease to confidence and

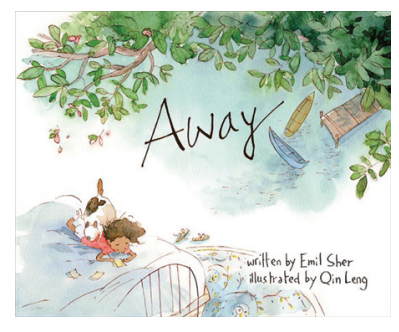
is presented entirely through illustrations and post-it notes. Qin Leng's captivating watercolour illustrations extend the brief yet evocative text, and Michael Solomon's design work here is spectacular. 
The Man with the Violin (2013)

Kathy Stinson

and Dušan Petricic

This outstanding story, based on an actual event arising out of a 2007 experiment by the Washington Post, celebrates the power of music and a child who is willing to stop and

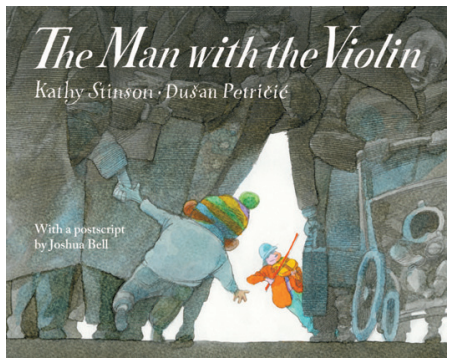
listen. World famous violinist Joshua Bell appeared in a subway station with his Stradivarius and played a free concert - and while adults passed him by, many children would have liked to pause and listen to him. Dušan Petricic's illustrations creatively use colour to present musical sounds and the effect music has on young listeners.

\section{The Wildlife 123: A Nature Counting Book (1989)}

Jan Thornhill

Similar to her clever alphabet book, The Wildlife $A B C$, first published in 1988, Jan Thornhill presents numbers in words and symbols alongside an interesting array of animals in their natural habitats, with the number of animals also repeated in colourful page borders. Flowing rhymes and a "nature notes" section at the end elevate the learning. Thornhill's exceptional artwork here far surpasses the typical fare in counting and alphabet titles.

\section{Ancient Thunder (2006)}

Leo Yerxa

Leo Yerxa was born in 1947 on the Little Eagle Reserve, Couchiching First Nation, in northwestern Ontario, and this collage-style book celebrates Indigenous art along with wild horses. The artist uses hand-made water colour paper, treated to look like leather, and then painted with bright watercolours mixed with gouache absolutely stunning. This book won a $2006 \mathrm{Gov}-$ ernor General's Award for Children's Illustration.

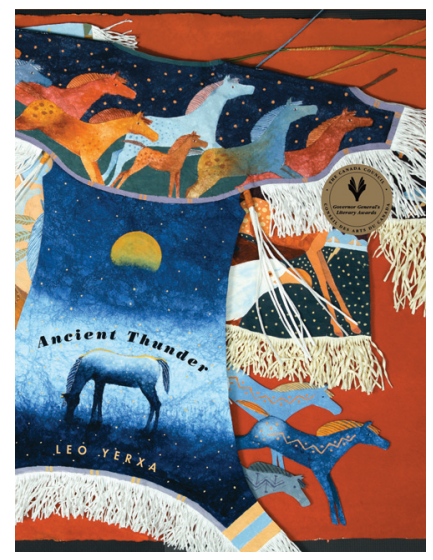


New perspectives can be seen in titles that include voices previously unheard in the picture book form. Adult characters appear in some of these books, dislodging an old idea about the necessity of child protagonists. Characters from various cultures and language groups often emerge from their authors' and illustrators' personal experiences. Characters with disabilities, who present as protagonists, add important points of view. We are cheering at the mirrors and windows here.

Where not otherwise indicated, the name of the author(s) appears first under each title, and the illustrator last.

The Blind Boy \& the Loon (2014)

Alethea Arnaquq-Baril

and Daniel Gies

This traditional Inuit story explains the origins of the narwhal, while warning against becoming sightless through a desire for revenge. Alethea Arnaquq-Baril is an Inuit filmmaker, animator, and documentarian. Daniel Gies' underwater scenes and Northern landscapes are haunting.

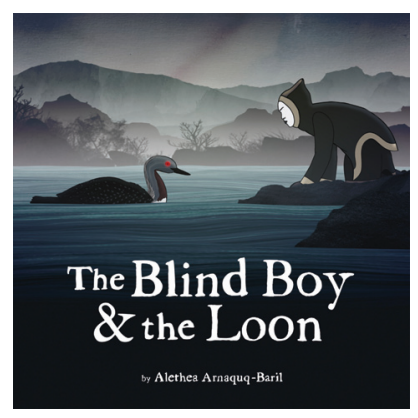

Long Powwow Nights (2009)

David Bouchard,

Pam Aleekuk,

Buffy Sainte-Marie (music),

Patsy Paul-Martin (translator)

and Leonard Paul

This book celebrates powwows and their significance to Indigenous people. Its narrator reflects upon his mother's love of the dance, and his mother's life and teachings as she grows older and passes away - a full circle not often presented in older picture book resources. The book contains dual English and Mi'kmaq text (while another version uses French/Mi'kmaq) as well as a CD recording that includes music by Buffy Sainte-Marie. David Bouchard's website identifies him as a Métis author and educator born in Saskatchewan; Leonard Paul's website indicates that he is a Mi'kmaq artist born in Halifax. 
Mabel Murple (1995/2010)

Sheree Fitch

and Sydney Smith

In delightful rhythm and rhyme, this story about a daring young girl, first published in 1995 when it was illustrated by Maryann Kovalski, celebrates a strong female character while at the same time honouring human differences. Sydney Smith's new illustrations are delightful in various degrees of purple, violet, mauve and plum.

Stella, Star of the Sea (1999)

Marie-Louise Gay

This story catapults a feisty female heroine into what eventually became a series of six "Stella" titles (along with others that focus on her younger brother, Sam). Marie-Louise Gay's body of work is hugely important in the realm of Canadian picture books - particularly noteworthy for its deep understanding

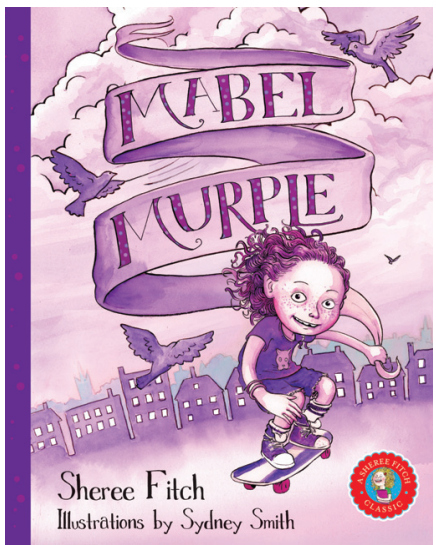
of the emotional world of children. Through

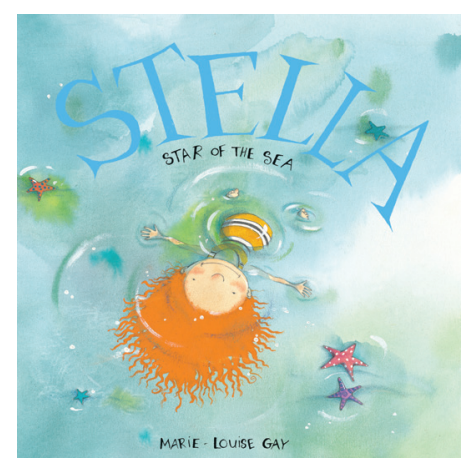
watercolour as well as dialogue, Gay skillfully depicts Stella and Sam, and the imaginative world they inhabit, with warmth and imagination.

Jillian Jiggs (1985)

Phoebe Gilman

Another strong heroine is championed in this title, the first of a series of books about a nontraditional girl in a context where creativity abounds. Phoebe Gilman, who taught at the Ontario College of Art, considered herself an artist first and foremost, with a profound love of words.

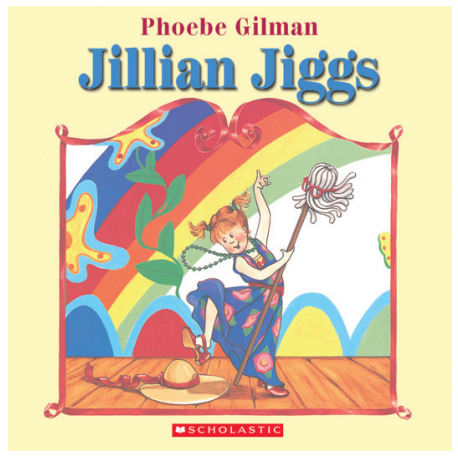


A Screaming Kind of Day (1999)

Rachna Gilmore

and Gordon Sauvé

Scully navigates her bad day by yanking out her hearing aids. A character presenting an exceptionality as one aspect of her characterisation was unusual at the time this book was published and is still uncommon on today's literary landscape. This beautiful book won the 1999 Governor General's Literary Award for its text. Gordon Sauvés high-realistic paintings were created with vivid acrylics, and superbly capture the heightened emotional content of this story.

Sweetest Kulu (2014)

Celina Kalluk

and Alexandria Neonakis

The birth of Kulu is a joyous time and northern animals arrive with lessons and gifts in this beautiful bedtime poem. The connectedness of our living Earth resounds here, and

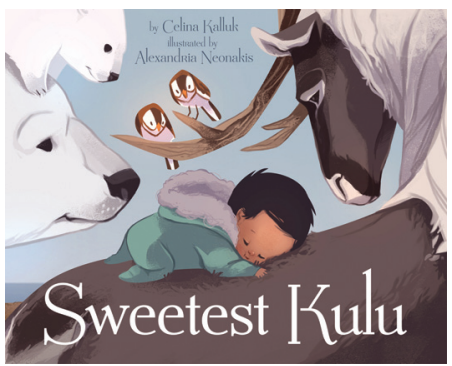
this title offers an experience of the Arctic world unique to the picture book format. Celina Kalluk is an Inuit-Canadian author from Resolute Bay, Nunavut. Alexandria Neonakis is from Nova Scotia; her illustrations here glow with warmth.

A Coyote Columbus Story (1992)

Thomas King

and Kent Monkman

This book presents a retelling of the Christopher Columbus story from an Indigenous point of view. Coyote, a trickster, unwittingly allows Columbus to bring about the downfall of Coyote's human friends. An important point here is that history is influenced by the perspective of the reporter. Kent Monkman's vivid illustrations complement the vibrant storyline and the book was a finalist for a Governor General's Literary Award.

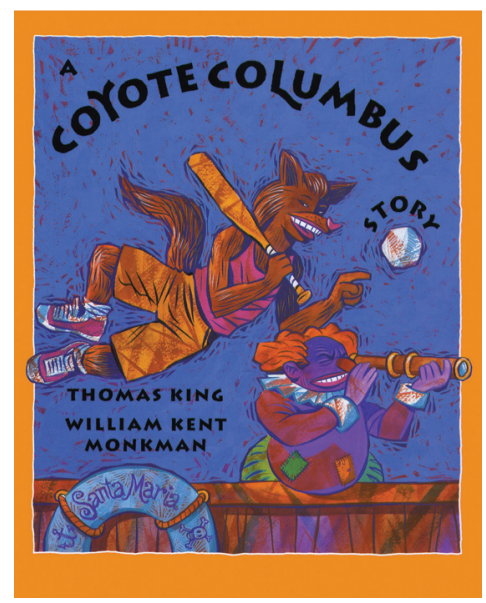


Amos's Sweater (1988)

Janet Lunn

and Kim LaFave

Amos the sheep is old and cold and wants his wool back. In a stellar picture book that has won both a Governor General's Literary Award and an Amelia Frances Howard-Gibbon Award for illustration, as well as the Ruth Schwartz Award, this title is on one level a terrifically funny animal story and, on another level, a story about advocating for one's rights.

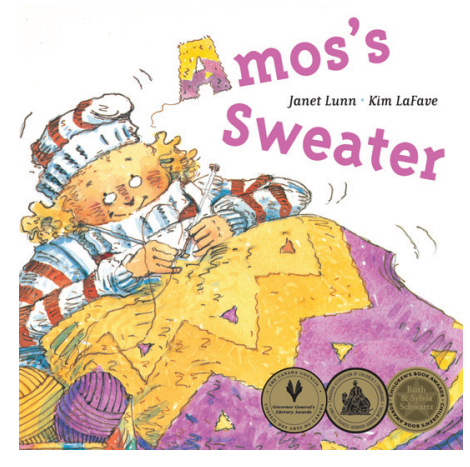

Dolphin sos (2014)

Roy Miki,

Slavia Miki

and Julie Flett

This serious picture book helps readers understand the tragedies experienced by dolphins trapped in ice flows. It presents local heroes as people who champion the natural world, and inspires its audience to

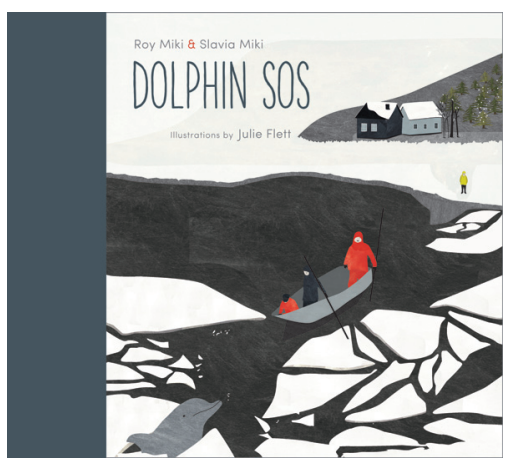
think about their own backyard, and what lies beyond it, with sustainability in mind. Julie Flett's stylised figures and digitally combined collage are spare and striking.

\section{Love You Forever (1986)}

Robert Munsch

and Sheila McGraw

Originally published in 1986, this is one of the best-selling Canadian paperback picture books of all time, with over 30 million copies sold in English as well as translations, and reaching intergenerational audiences with its story about the evolving parent-child relationship. However, this book has faced much controversy, with the discussion centring on whether the story depicts a mother's heartwarming and unending love or a creepy, unhealthy helicopter parent. 
The Paper Bag Princess (1980)

Robert Munsch

and Michael Martchenko

Princess Elizabeth reverses the princess and dragon stereotypical narrative while championing feminism, as haughty but well-dressed Prince Ronald is discarded for being "a bum." First published in

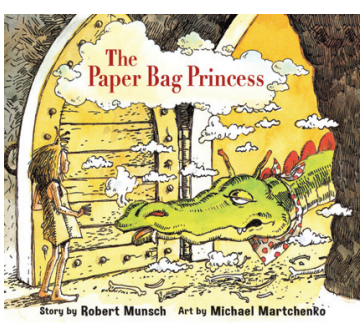

CLASSIC Y MUNSCH 1980, this book has won critical acclaim, including endorsement from the National Organization for Women. This was the first collaboration between Robert Munsch and Michael Martchenko, whose zany, comic style has become associated with Munsch works.

Red is Best (1982)

Kathy Stinson

and Robin Baird Lewis

This timeless tale of one child's stubborn preference for the colour red has won the hearts of readers for over 30 years. One of the authors of this guide loves this title so much that she carries around miniatures to give away to children in air-

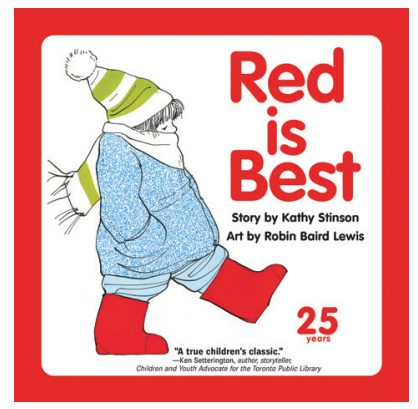
ports or other places where children are in need of something to read and delight in. The illustrator made a brilliant choice in the spare use of colour that showcases red so vibrantly.

\section{Chin Chiang and the Dragon's Dance (1984)} Ian Wallace

This spectacular title blends legend and reality with an authentic Chinatown setting and a reverence for both history and modern-day life. Winner of the Amelia Frances HowardGibbon Illustrator Award, the story itself dislodged stereotypes at the time of publication as its young hero finds the courage to be seen

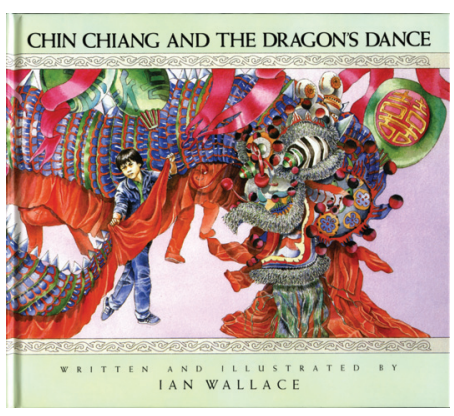
dancing. 
Viola Desmond Won't Be Budged! (2010)

Jody Warner

and Richard Rudnicki

This title narrates a true story about racism when an African Canadian is asked to move out of her theatre seat in 1946 Nova Scotia. Viola Desmond continues her fight against segregation with inspiring results, and a page on African Canadian history is included at the end of the book to further investigate the history of racism in Canada. Illustrations include accurate details of the Roseland Theatre along with a Pictou Advocate delivery truck, setting

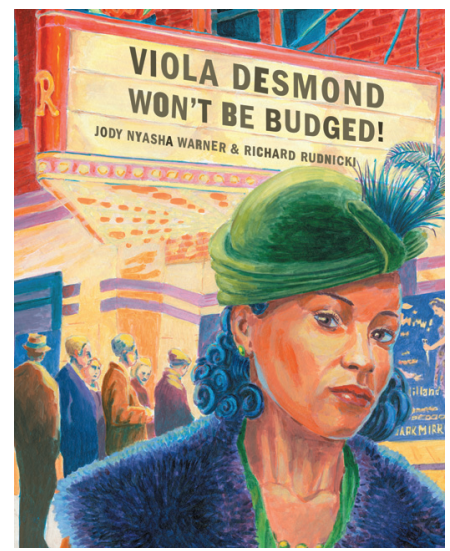
the scene carefully.

\section{3}

\section{Changing Boundaries}

Changing boundaries occur as serious subjects are increasingly represented, respecting the need for children to explore these topics in order to learn and grow. Diverse depictions of gender and sexuality also emerge in some of these titles, a rare element in children's literature until recently.

Canada has come a long way since the Canadian picture book Asha's Mums (written by Rosamund Elwin and Michele Paulse, illustrated by Dawn Lee) was banned in 2002 by a British Columbia school board and eventually reinstated by the Supreme Court of Canada, but we still seek equity in our range of offerings, encouraging authentic portrayals of the full range of human experiences. The book Stories for Every Classroom (Beverley Brenna, 2015) identifies various forms of children's literature, including picture books, that present characters with disabilities, and it specifically advocates for more representation of characters who are differently abled.

Many of the excellent books summarised in this section of "classics" are trailblazers that have inspired additional work in Canada, and beyond, to ensure that children will find important aspects of themselves and their world, past and present, illuminated in picture book form.

Where not otherwise indicated, the name of the author(s) appears first under each title, and the illustrator last. 
Shi-shi-etko (2005)

Nicola I. Campbell,

David Unger (translator)

and Kim LaFave

This is the story of a little girl whose mother prepares her to attend residential school. It was the winner of the Anskohk Aboriginal Children's Book of the Year, and a finalist for the TD Canadian Children's Literature Award, the Marilyn Baillie Picture Book

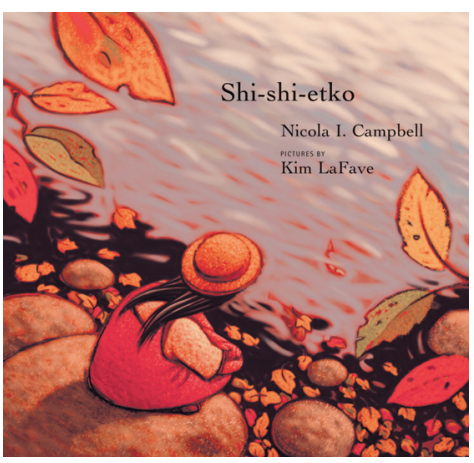
Award and the Ruth Schwartz Award.

How Smudge Came (1995)

Nan Gregory

and Ron Lightburn

This title, first published in 1995, follows Cindy, a young adult who lives in a group home and works as a cleaner in a hospice. The heart of the story involves Cindy's struggle for independence when she isn't allowed to have a puppy. Ron Lightburn's soft, pontillistic illustrations use coloured pencil on paper to depict Cindy as a character with Down Syndrome.

Not My Girl (2014)

Christy Jordan-Fenton,

Margaret Pokiak-Fenton

and Gabrielle Grimard

Margaret Pokiak-Fenton's story from When I Was Eight is continued in this title that addresses her difficult experiences returning home from residential school. Both picture books are adapta-

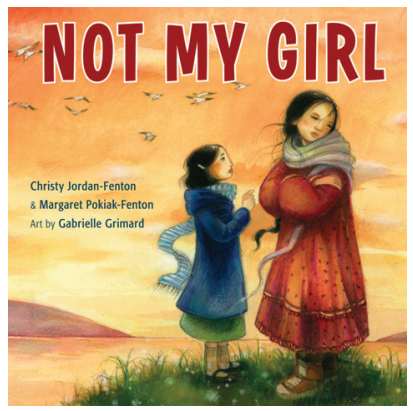
tions of award-winning novels for older readers (A Stranger at Home: A True Story, and Fatty Legs), and all Margaret Pokiak-Fenton's memoirs, in collaboration with daughter-in-law Christy Jordan-Fenton. 


\section{Virginia Wolf (2012)}

Kyo Maclear

and Isabelle Arsenault

Based on the early relationship between writer Virginia Woolf and her sister, Vanessa Bell, this title seamlessly introduces the theme of childhood depression. At the time of publication, the subject of mental health was not a strong presence in picture book resources. Isabelle Arsenault's illustrations are a striking blend of media: ink, pencil, watercolour, and gouache.

A Family is a Family is a Family (2016)

Sara O'Leary

and Qin Leng

Every student in a fictional class of 12 explains what makes their family special. Many different families are constructed here in a sequence that includes two moms or dads, single or separated parents, blended and foster families, and parents with exceptionalities. Qin Leng's soft pastel illustrations are characterful and captivating.

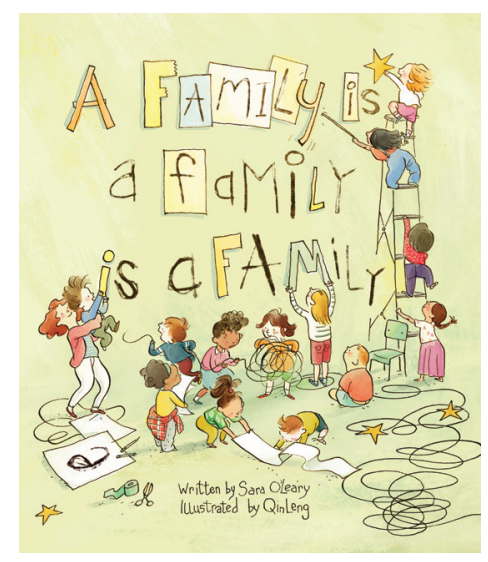

The Cremation of Sam McGee (1986)

Robert W. Service

and Ted Harrison

A classic Canadian ballad about death, cold, and dedication is illustrated in twelve brilliant paintings by artist Ted Harrison - including his signature layered landscapes and bold colour choices. Life in the Yukon is on stage here as well as serious subject matter for older readers. Its publication combined great lines for reading aloud with gallery-quality art work, at that time an innovative approach to children's illustrated books. 


\section{Scaredy Squirrel (2006)}

Mélanie Watt

This is the first title in Mélanie Watt's successful series about an anxiety-ridden squirrel. Many readers will identify with the individual differences presented here and benefit from considering the mental health supports - humorous in the forest context - provided to Scaredy throughout these empathetic books that offer a contemporary design, including narration, labels, and lists.

Ten Birds (2011)

Cybèle Young

This innovative story relates how ten curious birds each make their way across a demanding river. The intricate pen-and-ink illustrations portray a fabulous alternative world that offers positive room for individual qualities to shine, as well as a chance for children to practice their counting skills.

\section{Bibliography}

*In the spirit of the recommendations of the Truth and Reconciliation Commission, an asterisk appears beside works created by Indigenous writers or artists.

The editions below are not necessarily the originals; for original year of publication, please see titles in previous section.

*Arnaquq-Baril, Alethea (2013). The Blind Boy \& the Loon. Iqaluit, NU: Inhabit Media. Beck, Carolyn (illustrated by Andrea Beck) (2008). Buttercup's Lovely Day. Victoria, BC: Orca Book Publishers.

Blades, Ann (1971). Mary of Mile 18. Toronto, ON: Tundra Books/Penguin Random House.

*Bouchard, David \& Aleekuk, Pam (illustrated by Leonard Paul) (2009). Long Powwow Nights. Calgary, AB: Red Deer Press.

*Campbell, Nicola I. (illustrated by Kim LaFave, translated by David Unger) (2005). Shi-shi-etko. Toronto, ON: Groundwood Books/House of Anansi Press.

Carrier, Roch (illustrated by Sheldon Cohen, translated by Sheila Fischman) (1979/2014). The Hockey Sweater. Toronto, ON: Tundra Books/Penguin Random House.

Delaunois, Angèle (illustrated by Gérard Frischeteau, translated by Erin Woods) (2017). Water's Children: Creating the Resource that Unites Us All. Toronto, ON: Pajama Press. Fitch, Sheree (illustrated by Sydney Smith, original edition illustrated by Maryann Kovalski) (2010). Mabel Murple. Halifax, NS: Nimbus Publishing. 
*Flett, Julie (2010). Lii Yiiboo Nayaapiwak lii Swer: L'alfabet di Michif /Owls See Clearly at Night: A Michif Alphabet. Vancouver, BC: Simply Read Books.

Gay, Marie-Louise (1999). Stella, Star of the Sea. Toronto, ON: Groundwood Books/ House of Anansi Press.

Gilman, Phoebe (1985/2004). Jillian Jiggs. Markham, ON: Scholastic Canada.

Gilmore, Rachna (illustrated by Gordon Sauve) (1999). A Screaming Kind of Day. Toronto, ON: Fitzhenry \& Whiteside.

Gregory, Nan (illustrated by Ron Lightburn) (1995/2003). How Smudge Came. Red Deer, AB: Red Deer College Press.

*Jordan-Fenton, Christy \& Pokiak-Fenton, Margaret (illustrated by Gabrielle Grimard) (2014). Not My Girl. Toronto, ON: Annick Press.

*Kalluk, Celina (illustrated by Alexandria Neonakis) (2014). Sweetest Kulu. Iqaluit, NU: Inhabit Media.

*King, Thomas (illustrated by Kent Monkman) (1992). A Coyote Columbus Story. Toronto, ON: Groundwood Books/House of Anansi Press.

*Kusugak, Michael Arvaarluk (illustrated by Vladyana Krykorka) (1990). Baseball Bats for Christmas. Toronto, ON: Annick Press.

*Loyie, Larry \& Brissenden, Constance (illustrated by Heather D. Holmlund) (2002). As Long as the Rivers Flow. Toronto, ON: Groundwood Books/House of Anansi Press.

Lunn, Janet (illustrated by Kim LaFave) (1988). Amos's Sweater. Toronto, ON: Groundwood Books/House of Anansi Press.

Maclear, Kyo (illustrated by Isabelle Arsenault) (2012). Virginia Wolf. Toronto, ON: Kids Can Press.

McFarlane, Sheryl (illustrated by Ron Lightburn) (1991). Waiting for the Whales. Victoria, BC: Orca Book Publishers.

McGugan, Jim (illustrated by Murray Kimber) (1994).Josepha: A Prairie Boy's Story. Red Deer, AB: Red Deer College Press.

*Miki, Roy \& Miki, Slavia (illustrated by Julie Flett) (2014). Dolphin SOS. Victoria, BC: Tradewind Books.

Munsch, Robert (illustrated by Michael Martchenko) (1980). The Paper Bag Princess. Toronto, ON: Annick Press.

Munsch, Robert (illustrated by Michael Martchenko) (1985). Mortimer. Toronto, ON: Annick Press.

Munsch, Robert (illustrated by Sheila McGraw) (1995). Love You Forever. Richmond Hill, ON: Firefly Books.

O'Leary, Sara (illustrated by Qin Leng) (2016). A Family is a Family is a Family. Toronto, ON: Groundwood/House of Anansi Press.

Petricic, Dušan (2015). My Family Tree and Me. Toronto, ON: Kids Can Press.

Reid, Barbara (1997). The Party. Richmond Hill, ON: North Winds Press/Scholastic Canada. 
Service, Robert W. (illustrated by Ted Harrison) (1986/2006). The Cremation of Sam McGee. Toronto, ON: Kids Can Press.

Sher, Emil (illustrated by Qin Leng) (2017). Away. Groundwood Books/House of Anansi Press.

Stinson, Kathy (illustrated by Dušan Petricic) (2013). The Man with the Violin. Toronto, ON: Annick Press.

Stinson, Kathy (illustrated by Robin Baird Lewis) (1982). Red is Best. Toronto, ON: Annick Press.

Thornhill, Jan (1989). The Wildlife 123. Toronto, ON: Maple Tree Press.

Wallace, Ian (1984). Chin Chiang and the Dragon's Dance. Toronto, ON: Groundwood Books/House of Anansi Press.

Warner, Jody (illustrated by Richard Rudnicki) (2010). Viola Desmond Won't Be Budged! Toronto, ON: Groundwood Books/House of Anansi Press.

Watt, Mélanie (2006). Scaredy Squirrel. Toronto, ON: Kids Can Press.

*Yerxa, Leo (2006). Ancient Thunder. Toronto, ON: Groundwood Books/House of Anansi Press.

Young, Cybèle (2011). Ten Birds. Toronto, ON: Kids Can Press. 